\title{
Storytelling and Corporate Social Responsibility Reporting: A Case Study of Leading UK Retailers
}

\author{
Peter Jones ${ }^{1 *}$, Daphne Comfort ${ }^{1}$ \\ ${ }^{1}$ University of Gloucestershire, The Business School, Pallas Villa, Park Campus, GL 50 2RH Cheltenham, UNITED \\ KINGDOM
}

*Corresponding Author: pjones@glos.ac.uk

Citation: Jones, P. and Comfort, D. (2018). Storytelling and Corporate Social Responsibility Reporting: A Case Study of Leading UK Retailers. European Journal of Sustainable Development Research, 2(4), 46. https://doi.org/10.20897/ejosdr/3916

Published: October 6, 2018

\begin{abstract}
Stories, in one form or another, are probably as old as the human race, but in recent years, businesses have increasingly come to recognise the importance of storytelling. The aim of this paper is to offer an exploratory commentary on how storytelling is employed in the corporate social responsibility reporting process by the leading UK retailers. The paper begins with an outline of the characteristics of storytelling within the corporate world, and then reviews the ways storytelling is employed by the UK's top ten retailers' as part of their corporate social responsibility reporting processes. The paper identifies a number of storytelling formats, including photographs and images, video clips, messages and cameo case studies, used by the selected UK retailers, and offers some reflections on their current approaches to storytelling. While the stories employed by the selected retailers often have a strong human impact and can strike emotive chords, the authors would argue that stories can, at least partly, be misleading in that they do not necessarily fully reflect a retailer's corporate social responsibility record.
\end{abstract}

Keywords: stories, storytelling, corporate social responsibility, UK retailers

\section{INTRODUCTION}

Storytelling - simply defined as a means of sharing and interpreting experiences - is as old as the human race and is certainly much older than recorded history. Stories can be told in a variety of ways including pictures and photographs, messages, conversations, presentations, letters, audio and visual recordings and increasingly social media, and their power is widely recognised. Storytelling is embedded in people's everyday lives, and in recent years, there has been increasing recognition of the role of storytelling in the business world. Gill (2015, p.663) defined 'corporate storytelling' as 'the process of developing and delivering an organisation's message by using narration about people, the organisation, the past, visions for the future, social bonding and work itself, in order to create new point-of-view or reinforce an opinion or behaviour.' PricewaterhouseCoopers (2017, webpage) suggested that 'storytelling is one of the most powerful tools available to effective communicators' and Gupta (2015, webpage) argued that 'stories are an effective tool in the strategy process and for communicating and achieving strategic objectives.' More specifically, Johansen and Nielsen (2012), explored how storytelling can contribute to corporate social responsibility reporting and Garcia-Rosell (2017, p.105) examined 'the possibilities and challenges of using stories as vehicles for critically evaluating contemporary business practices and testing the moral and political boundaries of corporate social responsibility.'

During the last two decades European and US retailers have increasingly recognised the environmental, social and economic impacts of their business operations and growing numbers of them have publicly reported on their 
corporate social responsibility strategies and achievements designed to mitigate and manage these impacts (e.g. Lee et al., 2009; Jones et al., 2012.) However, the role of storytelling in the corporate social responsibility reporting process within the European retail industry has received little or no attention in the academic literature. With these observations in mind, the aims of this exploratory paper are twofold. Firstly, to provide a range of illustrations of the ways in which the UK's leading retailers have employed storytelling as part of the corporate social responsibility reporting process. Secondly, to offer some reflections on current approaches to storytelling in corporate social responsibility reporting within the retail industry.

\section{STORYTELLING AND RETAILING}

Storytelling has its roots in the origins of human civilisation and has traditionally been used to share, and pass on, knowledge, values, myths, legends, fables and religious beliefs, from one generation to another and across geographical space. Initially, storytelling was conducted though drawings and word of mouth communication, though over time the written, and then the printed, word became an increasingly important storytelling medium. More recently, developments in information and communication technologies, particularly social media, have seen storytelling become an increasingly all pervasive and all-embracing experience. Osman (2014, webpage), for example, argued 'transcending barriers of language and culture, storytelling is one of the oldest art forms in history, utilised to transmit cultural, moral and complex information in a simple, engaging and meaningful manner.' In many ways, stories inform and illuminate all walks of life and in recent years, the role of storytelling has attracted attention in the retail industry.

Within the retail industry, storytelling has traditionally been used to enable retailers to initiate and develop relationships with their customers. As such, storytelling is seen to be important in that it enables retailers to forge strong bonds with their customers and for customers to feel connected to the retail brand. Storytelling is thus seen to be vitally important in conveying what the retail brand stands for, and the provenance of that brand and its goods and services. While storytelling is a traditional method of communication it has found new and evolving expression with the dynamic retail marketplace. Jones et al. (2010, p. 241) outlined the emergence and development of experience stores' and almost a decade later VisualRetailing (2018, webpage) suggested 'we're living - and shopping - in the new customer experience' and 'the very idea of what a store is has changed. It's morphed from a place where people come to buy, to a place where people come to discover.' Pamela Danzinger (2017, webpage), the founder of Unity Marketing, argued 'retailers are discovering the way to move from a product-centric to a consumer-centric retail model is through storytelling' and that 'today retailers must focus on customers and the stories they want to hear.' Further VisualRetailing (2018, webpage) argued 'today's consumer no longer simply wants to buy - they're looking for a rewarding shopping experience, made of emotions - of stories. Stories make you feel things. They help convey information and help people retain information better.' Lisa Mukhedkar (2017, webpage), the co-founder of Restore, a retail design firm based in Bangalore, claimed 'retail storytelling is one of the most critical factors in creating a great experience for the customer. Stories that form an emotional connect with the customer are remembered for a long time.'

While the role of storytelling in marketing has attracted some attention from the academic researchers (e.g. Pulizzi, 2012; Hamond, 2017) research into the role of storytelling in retailing has been more limited. That said, Gilliam and Zablah (2013) suggested that product stories told from a business point of view were likely to be most effective in influencing customers' purchasing intentions in one-time sales encounters, while Gilliam and Flaherty (2015) explored the role that storytelling plays in the exchange between salesperson and buyer. Erickson and Carlsson (2014) revealed that slow fashion retailers were using storytelling to communicate their ideology to customers. More generally, Gilliam et al. (2014) identified a number of dimensions of retail storytelling, including story relevance, story humour and storytelling ability, and explored how they influenced consumer behaviour. Within the retail industry itself, in November 2017 Marketing Week (2017) announced that 'a study of UK brands finds Marks and Spencer is the best retailer for storytelling.' In examining the power of storytelling for Lush, the UK based handmade cosmetics retailer, Matheny (2015) described how the company's 'Oxford Street store pulls back the curtain to reveal the brand's mission and unveils its story through an immersive sensorial experience.' In looking to highlight the increasing importance of storytelling Danzinger (2017) suggested 'Timberland is doing it with its TreeLab concept where every 6-to-8 weeks the TreeLab store is made over to tell a new story with a curated selection of Timberland products elements in that story' and that 'perbaps the most story-intensive retailer is NYC's STORY Store, on 10 th Avenue in the Chelsea district' (of New York) where 'every 4-to-8 weeks the store reboots to bring in a whole new range of merchandise to tell a new story.'

\section{FRAME OF REFERENCE AND METHOD OF ENQUIRY}

The retail industry is a vital element in the UK economy, in 2017 it generated some $\AA_{4} 406$ billion of sales (House of Commons Library, 2018) and it is the country's largest private sector employer. There are some 290,000 retail outlets within the UK but there is marked concentration within the market with estimates suggesting that large 
European Journal of Sustainable Development Research, 2(4), 46

Table 1. Selected UK Retailers

\begin{tabular}{lccc}
\hline Retailer & Number of Outlets & Number of Employees & Traiding Format/Retail Sector \\
\hline Tesco & 6,500 & 476,000 & Supermarket/Convenience \\
\hline J. Sainsbury & 2,240 & 211,500 & Supermarket/Convenience $/$ Catalogue \\
\hline Wm. Morrison & 500 & 132,000 & Supermarket \\
\hline Kingfisher & 1,180 & 74,000 & Home Improvement \\
\hline Marks and Spencer & 1,330 & 85,000 & Department Store/Food \\
\hline Dixons Carphone & 2,140 & 43,000 & Electrical and Telecommunications \\
\hline John Lewis Partnership & 380 & 89,000 & Department Store/Supermarket \\
\hline The Cooperative & 6,500 & 70,000 & Supermarket/Convenience Store \\
\hline Primark & 325 & 68,000 & Clothing \\
\hline Next & 540 & 49,000 & Clothing
\end{tabular}

firms account for around 40 per cent of employment and 53 per cent of turnover' (House of Commons Committee on Exiting the European Union, 2017, p.3) and that the ten leading retailers account for almost $40 \%$ of all retail sales (Mesic, 2015). In an attempt to illustrate the ways in which storytelling has been employed in the sustainability reporting process in the retail industry within the UK, the top ten UK country of origin retailers, as measured by turnover (Deloitte, 2018), namely, Tesco, Sainsbury's, Morrisons, Kingfisher, Marks and Spencer, Dixons Carphone, John Lewis Partnership, The Cooperative, Primark and Next (Table 1) were selected for study.

While companies have employed a range of methods to report on their corporate social responsibility commitments and achievements, publication on corporate websites has become the most popular and the most accessible reporting mechanism (Morhardt, 2009). With this in mind, the authors conducted an Internet search for information, using the key phrase 'corporate social responsibility report' and the name of each of the selected retailers. This search conducted in May 2018, using Google as the search engine, revealed that the selected companies report on their corporate social responsibility commitments and achievements in a number of ways. Five of the selected companies namely Morrisons, Kingfisher, John Lewis Partnership, The Cooperative and Next posted a formal corporate social responsibility report. Tesco and Sainsbury's posted updates on their corporate social responsibility commitments and achievements. Marks and Spencer and Dixons Carphone posted a series of thematic reports, for example, focused upon environment, community and the supply chain and Primark posted an environmental performance report.

These corporate social responsibility reports and updates provided the empirical material for this paper and unless specifically cited all quotations are drawn from this material. In reviewing the material on corporate social responsibility posted by the selected retailers, the authors pursued an interpretivist approach in looking to explore how storytelling had been incorporated into corporate social responsibility reporting. The specific examples and selected quotations drawn from the storytelling elements are used for illustrative purposes, with the principal aim being on reviewing how the selected retailers employed storytelling in the corporate social responsibility reporting process and not on providing a comparative evaluation of the storytelling process.

The paper is based on information that was posted on the Internet, and thus in the public domain, and the authors took the view that they did not need to contact the selected retailers to obtain formal permission prior to conducting their research. When outlining the issues of reliability and validity in relation to information drawn from the Internet, Saunders et al. (2009) emphasised the importance of the authority and reputation of the source and the citation of a specific contact individual who might be approached for additional information. In reviewing the corporate social responsibility material, the authors were satisfied that these two conditions were met. At the same time the authors recognise that their study has its limitations not least that it is based on authors' designation and interpretation of the storytelling elements in these reports. That said the authors believe that their approach is appropriate in what is an exploratory study.

\section{FINDINGS}

All the top ten UK retailers employed storytelling to illustrate their corporate social responsibility commitments and achievements though there were marked variations in the extent to which stories were used. A number of themes can be identified. At the general level, the corporate social responsibility reports, updates and thematic reports, can themselves, be seen as stories, as explicitly titled by one of the selected retailers. In its 'corporate responsibility and society' update for the third quarter of 2017, Sainsbury's, for example, provided links to outline its achievements in helping customers to cut down food waste, inspiring children to lead healthier lives and working in the community with local charities under the banner 'Our Stories' and Kingfisher suggested that its approach to sustainability was found 'inside our company and in its stories.'

More specifically, messages, photographs and images, video clips, and cameo case studies were widely used, often in combination, in the corporate social responsibility material posted by the selected retailers. Messages from 
senior company executives were a prominent element of the corporate social responsibility reporting process. Perhaps the potentially most powerful messages, were from the Chief Executives of the selected retail companies. In her 'From our Chief Executive' message in Kingfisher's Sustainability Report 2016-2017, Veronique Laury, claimed 'our ambition is to become the leading home improvement retailer' and 'sustainability is at the core of our ambition' and 'we will build on our sustainability strategy during 2017, based on our customers' needs. We will focus on what really matters to them to impact their behaviours and to help them to have a more sustainable home.' In a similar vein, in his 'Chief Executive Introduction' to Morrison's 2016-2017 Corporate Responsibility Report, David Potts, emphasised 'we're making good progress on the issues that matter most to our customers' namely 'food safety, supporting British farmers, looking after our colleagues and buying British products.'

In his contribution to Tesco's update on its corporate responsibility commitments, Dave Lewis, Group Chief Executive, renewed his company's commitment to the United Nations Global Compact, which encourages businesses worldwide to adopt sustainable and socially responsible policies. More specifically, Dave Lewis argued it is unquestionable in my mind that Tesco has a responsibility to make a positive difference, taking small steps to help make sure that future generations have the same, if not better, opportunities than we do today.' In her 'Welcome' to Next's 2018 Corporate Responsibility Report, Amanda James, Group Finance Director, suggested 'as a global business within the retail sector, our corporate responsibilities touch on some big issues, which are significant to how we do business and how we operate as an employer and supply chain manger.' More specifically, the Group Finance Officer claimed Next operated by 'acting in an ethical manner, recognising, respecting and protecting human rights: developing positive relationships with our suppliers: taking care of our employees; being responsible for our impact on the environment; delivering value to our customer' and 'delivering support through charitable donations.'

Messages from employees at a range of levels within the selected retailers were also a common feature of the corporate social responsibility reporting process. Jon Hartland, Director of Non-Food Operations at Sainsbury's emphasised the importance the company attached to 'delivering great impact in our communities' with the following message. 'The work we do with our communities, with food donations, is absolutely critical. Our colleagues' commitment to local beroes, for example, is often eye-watering as is the effort they put into making their Charity of the Year such a success.' Marks and Spencer looked to reinforce the reporting of the success of the company's 'Global Community Programme' with a message from an 'Emerging Leaders Trainee in Kenya' who said 'Before the training, I did not think that people like me can lead a successful life. Now I believe it is possible.'

In reporting on an initiative to help reduce food waste by giving some 15,000 customers fridge thermometers to check if their fridge was operating at the correct temperature, Sainsbury's cited a short message from Rebeka Muldowney, one of the company's fridge thermometer testers, which read 'it's such a simple idea but can make such a difference.' In addressing its approach to its workforce, Morrisons included the following message from an employee who had followed the company graduate scheme. 'Morrisons graduate scheme has enabled me to experience roles which I had never before considered. I have been given lots of experience early on. All colleagues are very welcoming and have spent time developing me whether I have been in store or head office.' All these stories look to emphasise the selected retailers' employees' commitments to, and support for, corporate social responsibility and how such commitments touch everyday lives of their employees and help to enrich their work experience.

In number of cases, the selected retailers used messages from individuals and organisations outside their company to reinforce their corporate social responsibility commitments and achievements. Sally Uren, Chief Executive, Forum for the Future, provided 'An External Perspective 'to Kingfisher's 'Sustainability Report 2016-2017' which claimed 'this report gives three reasons to be confident that Kingfisher will be successful in delivering its ambition to be a truly sustainable company' namely, 'the ways in which sustainability drives commercial success', the criticality of the customer to Kingfisher's interpretation of sustainability' and the fact that 'this report is sprinkled with wonderful stories of innovation.' Morrisons looked to help emphasise its commitment to responsible sourcing with a message from Chloe North, the UK Fisheries Outreach Officer for the Marine Stewardship Council. The message read Project Fisheries Improvements is an ambitious project aiming to achieve an environmentally sustainable future for key commercial UK fisheries. This project would never have got off the ground without the support of Morrisons, along with other companies, coming together in a pre-competitive partnership.' The general story here is very much one of external endorsement of the selected retailers' approaches to corporate social responsibility.

Photographs and images were widely used to tell stories and they were employed in a variety of ways. The first page of Tesco's 2016 update on its corporate responsibility commitments, for example, was taken up by a photograph of a man working at the company's Community Food Connection partner charity at the Bethel Christian Centre in Dagenham. The story here was to reinforce Tesco's commitment to addressing food waste and to its support for food surplus donation programmes. The front page of The Co-operative's 2017 Ethics and Sustainability Performance Report', included photographs of company employees on a community programme, a number of wind turbines and a female agricultural worker on an African farm and here the story was to provide an initial signal of the company's commitment to the environment, the community and its international supply 
chain. Tesco's update on its environmental strategy was prefaced by an underwater photograph of a shoal of fish designed to complement the story of the company's commitment to natural ecosystems.

Photographs and images were also used to illustrate a number of specific environmental, social and economic themes as part of the corporate social responsibility reporting process. Dixons Carphone employed a photograph of an array of solar panels to illustrate its commitment to the environment and more specifically to energy management. Details of Dixons Carphone's partnership with The Mix, which works with young people facing problems from bullying, debt, drink and drugs, mental health, sexual health, homelessness, money, to relationships, included a picture of HRH Prince Harry at a charity musical event organised by The Mix. Morrisons illustrated its commitment to 'belp British farmers to be competitive, profitable and sustainable' with pictures of sheep and cattle grazing naturally. The John Lewis Partnership outlined Waitrose's description of its commitment to 'source and sell with integrity' which was illustrated by a photograph of a named lamb supplier pictured holding a traditional shepherd's crook in front of a flock of sheep in a rural landscape. More generally, a number of the photographs of people modelling the company's range of clothes, in Next's 2018 Corporate Responsibility Report are in natural settings. These photographs included a young boy running on a beach with mountains in the background, two young girls surrounded by flowers in an open woodland environment and a young woman walking to a sand dune coastline with a blue sea in the background. The underlying story here is of a company in harmony with the natural and cultural environment

A number of the selected retailers used photographs, images and video clips in describing their commitment to their workforce. Sainsbury's, for example illustrated its commitment to harness 'the talent, creativity and diversity' of 'our colleagues', with a number of photographs of smiling employees in their uniforms within the workplace environment. Morrison's commitment to 'look after our colleagues' was illustrated by photographs of a smiling checkout operator scanning products and of two employees smiling and seemingly chatting while refilling shelves in store. The Cooperative illustrated its commitment to diversity and inclusion with a photograph of a group of colleagues participating in the company's 'Diversity and Inclusion Pioneers' programme in a seminar room. The general story here is of a relaxed and happy working environment which offers a range of personal and professional development opportunities. Photographs were also used to emphasise the ways in which a number of the selected retailers work with communities as part of their corporate social responsibility commitments. Morrisons, for example, included photographs of a group of employees who had participated in a Sue Ryder Charity Cycle Event astride exercise bikes and holding collecting buckets.

In a three-minute video clip accessed from the Sainsbury's update, Paul Mills-Hicks, the company's Food Commercial Director, described the importance and relevance of sourcing with integrity. Within this clip Paul Hicks-Mills claimed that 'sourcing with integrity is at the heart of what differentiates us as a business.' Within this video clip he outlined the company's commitment to sourcing British products where possible and he encouraged all the company's employees to familiarise themselves with the 'stories' of sourcing with integrity and to promote these stories not only with customers but also with their family and friends. Angie Risley, Sainsbury's Human Resources Group Director, featured in a video clip in which she emphasised the importance the company attached to its sustainability plan and more specifically she emphasised that the company looks to address the issues and challenges that ensure that their employees feel cared for and valued so that they can 'create great customer service.' In another video clip, John Rogers, Sainsbury's Chief Financial Officer, recognised the range of impacts the business has not only on the national, but also the global, environment, and he outlined how the company was taking responsibility for mapping and managing these impacts and provided some information on a number of the specific initiatives the company was taking to reduce carbon emissions, water use and food waste. Dixons Carphone employed short video clips to illustrate its commitments to educational development in South Africa and to healthy lifestyles in the UK and Morrisons employed video to outline its programme to donate unsold food to charities.

Many of the selected UK retailers used a variety of cameo case studies as part of their approach to storytelling within the corporate social responsibility process. The John Lewis Partnership's Corporate Responsibility Report, for example, included a case study of investment in the efficiency and sustainability of Waitrose's transport fleet. More specifically, this case study reported how the company introduced 35 new biomethane trucks in 2017, which can run for up to 500 miles on the gas by-product of rotted vegetable matter and other food waste, while emitting over $80 \%$ less carbon dioxide than standard diesel alternatives. A further John Lewis Partnership case study on 'Ocean Stewardship' outlined how Waitrose used its 'purchasing power and expertise........ to influence positive change in global sourcing practices and to reassure customers that the fish they buy has been sourced responsibly.' Kingfisher employed a short case study of how Castorama Russia is using its Facebook and social media sites to engage customers on the benefits of a more sustainable home. The case study outlined how it's 'Choice for a Good Home' campaign, included ideas and tips to help customers plan an energy efficient bathroom as well as information on the benefits of energy efficient lighting and sustainable products. Primark's environmental performance report included three case studies of its surveillance testing results for poly fluorinated chemicals and a case study of how a dyeing mill in China, which 
supplied socks to Primark, agreed to adopt an internationally recognised verification procedure following the identification of wastewater discharge violations at the plant.

Marks and Spencer employed 13 case studies to help illustrate its 'Global Community Programme.' One of these case studies was focused on 'Sustainable Water Stewardship with Stone Fruit Growers in South Africa.' The case study outlined Marks and Spencer's work with stone fruit farmers in the Breede River basin, to develop a water stewardship programme designed around efficiency in water use, water quality monitoring, on-site wetland management and staff training. This programme is customised at the farm level in that 'each farm has taken action in different ways to adjust farming practices that use water or affect water levels or quality.' Dixons Carphone employed three case studies to illustrate its commitment 'Our Responsibilities.' The case study of the company's Blupoint project outlined how the Blupoint solar powered device, which transmits digital content to areas without reliable or affordable connectivity on any handset, using Wi-Fi, FM Radio or Bluetooth, was empowering local communities in South Africa with free internet access to educational tools and services. By way of contrast one of the other case studies was the 'Dixons Carphone Race to the Stones', which outlined the company's collaboration with Threshold Sports 'to transform the positioning and purpose of ultra-events into accessible ultraexperiences, attracting a diverse range of participants' while supporting 'charities looking for a demanding and rewarding addition to their fundraising portfolio.'

The Cooperative employed a case study on 'improving packaging recyclability' as part of its reporting on its approach to 'the environment and resource use.' This case study outlined how The Cooperative had 'continued to lead cross industry work to improve packaging recyclability, including engagement with local authorities and government to improve the UK recycling system.' The case study also outlined how the company had 'made several market leading innovations to increase the amount of plastics that can be recycled' including 'new cooked meat packaging' and 'new pizza packaging bases', and how the company had minimised the amount of black plastic in a number of product lines. Overall the company reported that ' $71 \%$ of our co-op branded packaging is easy to recycle.' Kingfisher used a short case study entitled Pro Grow A Circular Compost at $B \& Q$ ', with the strap line 'waste not want not' to illustrate its commitment to the circular economy. The case study outlined 'bow garden waste collected by Veolia (a waste management company) from households around the UK is turned into a peat-free rich compost that can be used to nurture new plants in our customers' gardens.'

\section{DISCUSSION}

Within the business world storytelling is seen to be increasingly important in bringing the corporate social responsibility reporting to life. The findings reported in this paper reveal that storytelling is certainly playing a part in addressing a range of environmental, social and economic agendas and achievements in the corporate social responsibility material posted by the UK's leading retailers. That said, three sets of issues merit reflection and discussion. Firstly, the stories cited above look to emphasise the leading UK retailers' commitments to corporate social responsibility and many of them strike potentially powerful emotive chords. The tone of the stories is exclusively positive in describing and illustrating the selected retailers' corporate social responsibility strategies, and more particularly their specific actions and achievements, in a favourable light. As such, the stories might be seen to reflect Leinaweaver's (2015) claim, that many corporate sustainability reports have perfectly scripted stories, and are stories told to create a party line

Within the social realm, stories featuring employees, for example, paint a picture of a committed and caring employer, of the provision of a wide range of development opportunities within the workplace and of a happy and loyal workforce. In a similar vein, stories about the selected retailers' commitments to the communities in which they operate are very much within the spirit of both economic and social community development. A common thread running through stories with an environmental theme is a commitment to stewardship and to the conservation of natural resources. More generally, some of the stories within the selected retailers' corporate social reports and updates reflect wider corporate goals. In her message in Next's corporate responsibility report Amanda James, Group Finance Director, for example, emphasised that the company's 'corporate responsibility focus ..... aims to bring value to all our stakeholders.' At the same time, the retailers' enthusiasm to develop and publicise positive corporate social responsibility stories might be seen to reflect the conclusions of research by Schramm-Klein et al. (2016, p.550) namely that 'CSR has positive implications as driver of customer loyalty and favourable consumer purchasing behaviour.'

However, the underlying messages from the stories in the selected companies' corporate social responsibility reports and updates, stands in marked contrast to a number of rather different stories about the impact the retail industry is having on the environment, society and the economy. The Tescopoly Alliance (2018a, webpage), for example, which claims to be 'campaigning to curb supermarket power', was founded in 2005 'to highlight and challenge the negative impacts of Tesco's behaviour along its supply chains both in the UK and internationally, on small businesses, on workers, on communities and the environment.' The Alliance claims to represent a diverse range of organisations and its founding members included Friends of the Earth, War on Want, the New Economics Foundation, Banana Link, Labour Behind the Label and the GMB trade union. The Tescopoly Alliance campaigns on a number of issues including 
national and local planning policies, the supermarket code of practice introduced in 2002, workers' rights and blocking the takeover of existing retail chains by the four leading UK food retailers.

More specifically, the Tescopoly Alliance (2018b, webpage) has explored the impact of the supermarkets on 'farmers, workers, the environment, food poverty, unhealthy food and animal welfare.' In reviewing the impact on farmers, for example, the Tescopoly Alliance (2018 c, webpage) claimed that thousands of farmers and farmworkers are forced to leave agriculture each year because of the low prices they receive for their produce. Farmers' organisations believe that a major contributory factor to this crisis in British farming is the increasing buying power of supermarkets and their ability to squeeze suppliers.' Further the Tescopoly Alliance (2018c, webpage) argued that 'supermarkets control nearly 80\% of the British grocery market and as the most powerful players along most food supply chains are able to dictate terms, conditions and prices to suppliers. If suppliers complain, supermarkets can simply move their business elsewhere, and their dominance of the food retail sector is such that there may simply be no one else for farmers to sell theirproduce to.' In reviewing the proposed merger between Sainsbury's and Asda announced in 2018, the Food Ethics Council (2018, webpage), for example, argued that 'the promise of ever cheaper prices - which at first sight may seem appealing - bides issues of who or what is being exploited in order to be able to deliver those lower prices.' In a similar vein, Corporate Watch (2010) argued 'supermarket purchasing and category management policies are effectively the antithesis of local sourcing?

In addressing planning, the Tescopoly Alliance (2018d, webpage) argued in the 1970s and 1980s, planning laws were relaxed, and allowed a large amount of out-of-town supermarket development. By the 1990s, it was clear that massive superstores relying on car-use and bulk buying were killing the High Street and were not socially or environmentally sustainable.' In focusing on local plans, the Tescopoly Alliance (2018b, webpage) suggested that 'local authorities should develop positive initiatives to encourage more sustainable forms of retail and protect independent shops. Islington's Local Plan, for example, encouraged initiatives such as co-operatives and street trading and providing support for small shops.' The Tescopoly Alliance (2018b, webpage) also criticised 'the practice by the largest retail chains of holding on to a massive land bank of properties' and 'the practice of retailers placing restrictive covenants on land to stop a competitor moving in', which were described as 'a barrier for small chains entering the market.'

Greenpeace (2018a, webpage), which looks 'to defend the natural world .......by investigating, exposing and confronting environmental abuse', reported that 'in the UK, supermarkets produce almost 1 million tonnes of plastic each year' and argued that supermarkets 'use loads of excess plastic packaging - so even if you want to reduce your own personal plastic footprint, the moment you do your daily food shop you are inundated with fruit and veg wrapped in plastic.' Further Greenpeace (2018b, webpage) reported that on Earth Day (April 22) 2018 'volunteers took action to higblight supermarkets' plastic packaging problem' by visiting a number of stores and replacing the plastic fruit and vegetable bags with paper ones and relabelling 'the shelves of overly-packaged fruit and veg to highlight the problem.' In the past, Friends of the Earth (2007) has also organised campaigns to highlight what the organisation saw as the negative impacts of supermarkets. Many of the concerns cited above are fiercely contested by the retail industry, but they present a very different image of the corporate retail world to that portrayed in the stories many of the leading UK retailers employ in their corporate social responsibility reports.

Secondly, there are issues surrounding the relationship between the 'particular' and the 'general', in that the stories employed in the retailers' corporate social responsibility reporting process, focus on specific individuals, events and initiatives, and as such can be seen to be specially chosen and choreographed by the selected retailers. These stories may well have a strong human interest, and some of them certainly have a powerful emotive appeal, which may well resonate with audiences on corporate websites and social media. However, they cannot necessarily be seen to be representative of the leading UK retailers' corporate social responsibility agendas and achievements. More cynically, the UK's leading food retailers might be seen to be taking the view that such stories may play a valuable role in directing attention away from concerns often expressed in the mainstream media, in pressure group publications and on their websites, and on social media, about the environmental, social and economic impact of their business activities. That is not, of course, to call into question the voracity and/or the integrity of the stories themselves, but rather to suggest that the UK's leading retailers need to more fully address the extent to which the stories they employ are indeed a true representation of their corporate social responsibility commitments and achievements.

Here, concerns can be identified at a corporate and an ethical level. At the corporate level, the issues of materiality and assurance loom large. Materiality is concerned with how corporate social responsibility issues deemed to be most important to a company, and crucially to all its stakeholders, are determined, while assurance is concerned with how the companies provide independent external verification of the information contained in their published corporate social responsibility reports and updates. A number of the selected retailers, including Morrisons, The Cooperative, John Lewis Partnership and Next, provided information on how stakeholder engagement contributed to the identification and prioritisation of the corporate social responsibility challenges perceived to be facing the company, but this practice was not universal amongst the selected retailers. As such, the stories used to illustrate a number of the corporate social responsibility issues identified by the selected retailers might be seen to reflect strategic corporate thinking rather than wider stakeholder concerns. A number of the 
selected retailers, including Morrisons, John Lewis Partnership and Next, provided independent assurance statements, as part of their reporting process, but these statements were often limited to a small number of issues rather than to the full spectrum of corporate social responsibility agendas and achievements. At the same time, the majority of the selected retailers did not report on commissioning assurance exercises. Here again, while specific stories were used to illustrate many of the environmental, social and economic issues in the selected retailers' corporate social responsibility reports and updates, their more general applicability might be seen to be called into question by the lack of independent external assurance.

Ethical concerns might be seen to arise when employees are approached to publicly endorse a specific element of a retailer's corporate social responsibility strategy or achievements. Such approaches could put potential respondents in a difficult position in that a rank and file employee might feel that a refusal to provide a positive endorsement could prejudice her/his current employment position or future career progression. While many retailers might be reluctant to countenance such concerns, media reports have suggested that attempts to encourage suppliers to publicly disclose details of concerns about their relationships with the large food retailers are generally met with a wall of silence (e.g. The Guardian 2015). More generally, Maagaard (2014) explored the role of messages from BP and Walmart employees as a strategy in corporate image management. In addressing the authenticity of such messages, Maagaard (2014, p. 31) argued that 'employees must be seen to mean what they say, and not merely be a mouthpiece for the management' and concluded that employees messages 'put into relief not only the difficult balance between authenticity and promotional force in corporate communication, but also the entanglement of participant roles, in organizations' coconstruction of employee stories to serve strategic purposes.'

Thirdly, and more generally, in many ways the storytelling process within the selected retailers' corporate social responsibility reports and updates reviewed in this paper, is by and large, traditional and conservative in style in that there is, at best, only limited attempts to harness rapidly evolving developments in information and communication technologies in this process. Amesheva (2017, webpage), for example, suggested that technological innovations that 'enable real-time data collection and reporting, new methods of communication and number-crunching is set to transform the world of corporate social responsibility.' In a similar vein Morin and Muruganathan (2017, webpage) argued that new developments in information and communication technologies offer 'creative ways to share sustainability stories' and to create 'real human stories for a wide audience.' More specifically, Morin and Muruganathan (2017, webpage) suggested that companies can now 'liberate the content in their sustainability reports', for example, by improved accessibility, the development of engaging content, digital videos and documentaries and data visualisation tools. Recognising that 'corporate social responsibility today is a major drive for a company's public image and the strength of their respective brands', Wille et al. (2014) developed a computer aided model for interactive corporate social responsibility campaigns using storytelling.

However, how far many large retailers will choose to go in embracing such innovations and in effectively providing wholesale and transparent public access to corporate social responsibility information and, more specifically, to stories remains be seen. That said, such innovations will surely provide exciting new vehicles for storytelling within the corporate social responsibility reporting process. As such, innovatively presented stories may find a receptive audience amongst many stakeholders who are increasingly conscious of, and open to, sophisticated methods of communication and reporting. At the same time such an approach may allow companies to illustrate their corporate social responsibility achievements with seemingly compelling stories that can seem so seductive and vivid that they effectively mask the bigger, and possibly less appealing picture.

\section{CONCLUSIONS}

Storytelling has grown in importance within the world of business and it is now commonly employed, for example, in public relations, communications management and marketing. More specifically stories are increasingly being used as an integral element in corporate social responsibility reporting. This paper reviews the ways stories have been used in the corporate social responsibility reporting process by the UK's leading retailers and identifies a number of approaches to storytelling, namely, photographs and images, video clips, personal messages and cameo case studies. While such stories often have a powerful human appeal and can strike emotive chords, the authors would argue that stories can, in part, be potentially misleading in that they do not necessarily fully reflect a company's corporate social responsibility record. More contentiously, positive stories with a potentially powerful emotive human appeal might be seen to mask a more accurate record of a company's corporate social responsibility achievements. That said, Sutton's (2017) argument, that there is no role for storytelling in corporate social responsibility reports, might be considered extreme and seems unlikely to find favour amongst the leading players within the UK retail industry. More positively, it is important that a range of stakeholders including investors, employees, consumers, the media, governments and pressures groups, as well as academic commentators, look to rigorously review the corporate social responsibility reporting process and the role of storytelling within that process. The authors recognise that this exploratory paper has a number of limitations, as outlined earlier, but they 
believe it provides an initial commentary on storytelling in the corporate social responsibility reporting process within UK retailing, and that, as such, it provides a platform for future research. Looking to the future, academic research might, on the one hand profitably look, to include studies of how other retailers not only in the UK but also elsewhere in the world, employ storytelling within their corporate social responsibility reporting process, of how such stories are identified and developed within companies, and of if, and how, customers' perceptions of, and responses to, such stories influences buying behaviour. On the other hand, it is important to recognise that corporate social responsibility reports potentially have a range of audiences including supply chain partners, investors, employees, the media and regulatory bodies and fruitful lines of research surely lie in understanding how these audiences receive and interpret social responsibility stories. More generally, continuing research might allow the development of a conceptual model both of different types of storytelling and also of how stories are captured and generated, edited, and moderated within organisations, which might, in turn, offer a framework to guide and structure future research work in this field.

\section{REFERENCES}

Amesheva, I. (2017). Five Technology Trends in Defining the Future of Corporate Sustainability. Available at: http://www.eco-business.com/opinion/ five-technology-trends-defining-the-future-of-corporatesustainability/ (Accessed 6 November 2017).

Danzinger, P. N. (2017). Story-Based Retail and the Evolving Role of the Merchandiser. Available at: https://www.forbes.com/sites/pamdanziger/2017/12/18/story-based-retail-and-the-evolving-role-ofmerchandiser/\#36b9aa9626c2 (Accessed 4 May 2018)

Deloitte. (2018). Global Powers of Retailing 2018. Available at: https://www2.deloitte.com/content/dam/Deloitte/at/Documents/about-deloitte/global-powers-ofretailing-2018.pdf (Accessed 3 May 2018)

Erickson, J. and Carlsson, N. (2014). Slow Fashion and how it is being communicated: The role of storytelling in engaging consumers in slow fashion. Available at: http://bada.hb.se/bitstream/2320/14303/1/2014.11.02.pdf (Accessed 7 May 2018)

Food Ethics Council. (2018). Supermarket mergers - Why ever bigger is not necessarily always better. Available at: https://www.foodethicscouncil.org/blog/175/19/Supermarket-mergers-why-ever-bigger-is-not-necessarilyalways-best/ (Accessed 9 May 2018)

Friends of the Earth. (2007). Making a strong case against supermarkets', Available at: https://friendsoftheearth.uk/sites/default/files/downloads/decision_notices.pdf (Accessed 26 April 2018) (Accessed 9 May 2018)

Garcia-Rosell, J-C. (2017). Corporate Social Responsibility Learning through Collaborative Storytelling. Available at: http://eprints.bournemouth.ac.uk/29699/7/EuroTEFI_2017_Proceedings_11_Aug_2017.pdf (Accessed 24 October 2017)

Gill, R. (2015). Why the PR Strategy of Storytelling Improves Employee Engagement and Add Value to CSR: An integrated literature Review. Public Relations Review, 41, 662-674. https://doi.org/10.1016/j.pubrev.2014.02.012

Gilliam, D. A. and Flaherty, K. (2015). Storytelling by the sales force and its effect on buyer-seller exchange. Industrial Marketing Management, 46, 132-142. https:/ / doi.org/10.1016/j.indmarman.2015.01.013

Gilliam, D. A. and Zablah, A. R. (2013). Storytelling during Retail Sales Encounters. Journal of Retailing and Consumer Services, 20, 488-494. https://doi.org/10.1016/j.jretconser.2013.04.005

Gilliam, D. A., Flaherty, K. E. and Rayburn, S. W. (2014). The Dimensions of Storytelling by Retail Salespersons', International Review of Retail. Distribution and Consumer Research, 24, 242-251. https://doi.org/10.1080/09593969.2013.849611

Gupta, M. (2015). How Strategic Leaders Use Storytelling. Available at: http://www.strategicthinking.eu/howstrategic-leaders-use-storytelling/ (Accessed 24 October 2017).

Greenpeace. (2018a). What We Do. Available at: https://www.greenpeace.org.uk/what-we-do/ (Accessed 26 April 2018)

Greenpeace. (2018b). This Earth Day We Asked Supermarkets to Reduce Their Plastic Footprint. Available at: https://www.greenpeace.org.uk/earth-day-asked-supermarkets-reduce-plastic-footprint/ (Accessed 26 April 2018)

Hammond, K. (2017). Storytelling in Your Marketing Efforts. Available at: http://www.business2community.com/marketing/importance-using-storytelling-marketing-efforts01831875\#YeSmy3K6qtSLCYum.97 (Accessed 24 October 2017)

House of Commons Library. (2018). The Retail Industry: Statistics and Policy. Available at: https://researchbriefings.parliament.uk/ResearchBriefing/Summary/SN06186 (Accessed 5 May 2018) 
House of Commons Committee on Exiting the European Union. (2017). Retail Sector Report. Available at: https://www.parliament.uk/documents/commons-committees/Exiting-the-European-Union/1719/Sectoral\%20Analyses/31-Retail-Report.pdf (Accessed 5 May 2018)

Johansen, T. S. and Nielsen, A. E. (2012). CSR in Corporate storytelling- legitimacy as a question of differentiation and conformity. Corporate Communications: An International Journal, 17, 434-448. https://doi.org/10.1108/13563281211274130

Jones, P., Comfort, D., Clarke-Hill, C. and Hillier, D. (2010). Retail experience stores: experiencing the brand at first hand. Marketing Intelligence and Planning, 28(3), 241-248. https://doi.org/10.1108/02634501011041408

Jones, P., Comfort, D. and Hillier, D. (2012). Sustainability in the European Shop Window. European Retail Research, In: Rudolph T., Foscht T., Morschett D., Schnedlitz P., Schramm-Klein H., Swoboda B. (eds) European Retail Research. European Retail Research. Gabler Verlag, Wiesbaden. https://doi.org/10.1007/978-38349-4237-1_1

Lee, M-Y., Fairhurst, A. and Wesley, S. (2009). Corporate Social Responsibility: A Review of the TOP 100 Us Retailers. Corporate Responsibility Review, 12(2), 140-158. https://doi.org/10.1057/crr.2009.10

Leinaweaver, J. (2015). Storytelling for Sustainability: Deepening the Case for Change. Abingdon: Routledge

Maagaard, C. (2014). Employee testimonials: Animating corporate messages through employees' stories. Discourse, Context and Media, 6, 22-32. https://doi.org/10.1016/j.dcm.2014.07.001

Marketing Week. (2017). M\&S is the UK's top storytelling retailer. Available at: https://www.marketingweek.com/2017/11/14/ms-uks-top-storytelling-retailer/ (Accessed 19 April 2018)

Matheny, R. L. (2015). The Lush Story. Available at: http://www.vmsd.com/content/lush-story (Accessed 19 April 2018)

Mesic, I. (2015). Concentration of the Retail Trade. Available at: file:// C:/Users/Asua/AppData/Local/Temp/3872-Article\%20Text-10469-1-10-20160111-2.pdf (Accessed 5 May 2015)

Morhardt, J. E. (2009). Corporate Social Responsibility and Sustainability Reporting on the Internet. Business Strategy and the Environment, 19, 436-452. https://doi.org/10.1002/bse.657

Morin, I. and Muruganathan, K. (2017). Innovation in Sustainability Reporting: New Design Trends and Digital Solutions for Powerful Storytelling. Available at: http://www.eco-business.com/opinion/innovation-insustainability-reporting-new-design-trends-and-digital-solutions-for-powerful-storytelling/（Accessed 23 October 2017)

Mukhedkar, L. (2017). Retail Storytelling - An Art of Building a More Human Brand. Available at: https:/ /www.entrepreneur.com/article/292301 (Accessed 4 May 2018)

Osman, K. (2014). Telling Tales - Storytelling as a Marketing Technique for the Travel, Tourism and Hospitality Industry. Available at: http://www.travel-ink.com/telling-tales-storytelling-as-a-marketing-technique-for-thetravel-tourism-and-hospitality-industry/ (Accessed 6 April 2018)

PricewaterhouseCoopers. (2017). Storytelling in Business. at: http://www.pwcacademy.lu/Pages/courses/storytelling.aspx (Accessed 24 October 2017).

Pulizzi, J. (2012). The Rise of Storytelling as the New Marketing. Publishing Research Quarterly, 6(2), 116-123. https://doi.org/10.1007/s12109-012-9264-5

Saunders, M., Lewis, P. and Thornhill, A. (2009). Research Methods for Business Students. Harlow: Prentice-Hall.

Schramm-Klein, H., Zentes, J., Steinmann, S., Swoboda, B. and Morschett, D. (2016). Retailer Corporate Social Responsibility is Relevant to Consumer Behaviour. Business and Society, 55(4), 550-575. https://doi.org/10.1177/0007650313501844

Sutton, J. (2017). Why There Is No Role for Storytelling in Your Sustainability Report. Available at: http://www.sustainablebrands.com/news_and_views/marketing_comms/jeff_sutton/why_there_no_role_st orytelling_your_sustainability_report (Accessed 3 November 2017)

Tescopoly. (2018a). About Us. Available at: http://www.tescopoly.org/about-us (Accessed 26 April 2018)

Tescopoly. (2018b). Issues and Impacts. Available at: http://www.tescopoly.org/issues-and-impacts (Accessed 9 May 2018)

Tescopoly. (2018c). Farmers. Available at: http://www.tescopoly.org/farmers (accessed 9 May 2018)

Tescopoly. (2018d). Planning. Available at: http://www.tescopoly.org/planning (Accessed 26 April 2018)

The Guardian. (2015). Supermarkets behaving badly - how suppliers can get a fairer deal. Available at: https://www.theguardian.com/small-business-network/2015/jun/25/tesco-supermarkets-behaving-badlysuppliers (Accessed 24 April 2018) 
VisualRetailing. (2018). The Power of Storytelling in Visual Merchandising. Available at: https://visualretailing.com/blog/2018/2/the-power-of-storytelling-in-visual-merchandising (Accessed 4 May 2018)

Wille, P., Finster, B. and Balke, W-T. (2014). A model for Interactive Corporate Social Responsibility Campaigns using Storytelling. Available at: http://www.ifis.cs.tu-bs.de/sites/default/files/A-Model-for-Interactive-CSRCampaigns-using-Storytelling.pdf (Accessed 14 April 2018) 